\title{
A Rapid Protocol for Isolating Genomic DNA from Tropical Grass Species Suitable for RAPD, ISSR and STS
}

\author{
Amaresh Chandra* and Raghvendra Saxena \\ Crop Improvement Division, Indian Grassland and Fodder Research Institute, Jhansi-284003, India
}

Received July 24, 2007; accepted August 20, 2007

\begin{abstract}
Summary Largely in apomictic tropical grasses molecular markers analyses including identifying genes through association genetics approach requires DNA from large numbers of samples in short span of time. A simple protocol for DNA isolation from 5 apomictic tropical grass species namely Dichanthium annulatum, Heteropogon concortus, Sehima nervosum, Chrysopogon fulvus and Cenchrus glaucus is described. The method allows DNA extraction from as little as 0.2 to $0.3 \mathrm{~g}$ of leaves ground in liquid nitrogen, followed by DNA isolation in $1.5 \mathrm{ml}$ Eppendorf tubes involving modified cetyltrimethylammonium bromide $(\mathrm{CTAB})$ procedure using $1 \%$ polyvinylpyrrolidone (PVP) to remove polysaccharides. By using the method, a DNA yield up to $345 \mu \mathrm{g} / \mathrm{g}$ leaf tissues was obtained. The quality of the DNA was quite suitable not only for PCR-based markers analyses but also for restriction enzyme digestion. No or insignificant DNA was obtained in plant samples extracted from the fixed solution (alcohol, alcohol and chloroform, alcohol and ethylene diamine tetra acetic acid (EDTA)), thus the use of liquid nitrogen was inevitable.
\end{abstract}

Key words Apomictic grass, CTAB, DNA isolation, Genomic DNA, ISSR, RAPD, STS

Facultative and obligate nature of apomixis in tropical grasses hinders the development of genetic stocks viz., $\mathrm{F}_{2}$, RIL and NIL. These are important starting materials required in molecular plant breeding for the development of genetic maps, identification of markers and QTLs for different agronomically important traits. Tackling such situations the association genetics are preferred which requires DNA from large numbers of individual plants. Good quality of genomic DNA is also required to construct the genomic DNA library to isolate abiotic stress related genes especially from those crops growing under extreme harsh and dry conditions.

Contamination with polysaccharides, phenolics and secondary metabolites is a common problem when isolating DNA from plant parts (Pandey et al. 1996), specifically from the plants species growing abettedly under harsh and extreme dry conditions. High contents of polysaccharides and lignin are some of the prominent specific problems observed in tropical grasses. The method involves a modified cetyltrimethylammonium bromide (CTAB) procedure based on that of Murray and Thompson (1980) and additional extraction with chloroform and correct proportion of 2-mercaptoethanol and polyvinylpyrrolidone (PVP). Surprisingly in case of Cenchrus glaucus this procedure did not yield good quality DNA. However, using SDS in place of CTAB, this species yielded good quality DNA. The DNA obtained through these 2 protocols is a good substrate for restriction endonucleases and polymerase chain reaction.

In light of IPR regime, DNA fingerprinting and cataloguing of the important and unique accessions, the preparation of good quality and quantity DNA has became a major concern. DNA extraction from tissues needs to be simple, rapid, inexpensive, and effective when many samples are used as in case of apomictic grasses where association genetics study requires genotyping several thousands of individual plants. To economize further to avoid the use of liquid nitrogen, method of iso-

* Corresponding author, e-mail: amaresh62@yahoo.com 
lating DNA after fixing them in alcohol, alcohol and chloroform, alcohol and ethylene diamine tetra acetic acid (EDTA) (Sharma et al. 2003) was attempted with tropical grasses. However, this method failed because DNA was unstable and degraded in course of isolation.

Materials and methods

\section{Solutions}

CTAB extraction buffer: 2\% (w/v) CTAB, 1.4\% (w/v) NaCl, $100 \mathrm{mM}$ Tris- $\mathrm{HCl}(\mathrm{pH} 8), 20 \mathrm{mM}$ EDTA (pH 8), 3-6\% 2-mercaptoethanol (v/v), \% PVP (w/v). Extraction buffer 'S': 2\% (w/v) SDS, $100 \mathrm{mM}$ Tris- $\mathrm{HCl}$ (pH 8), $50 \mathrm{mM}$ EDTA (pH 8), $100 \mathrm{mM} \mathrm{NaCl}$. Chloroform-isoamylalcohol $24: 1$ (v/v). TE buffer: $10 \mathrm{mM}$ Tris- $\mathrm{HCl}(\mathrm{pH} 8), 1 \mathrm{mM}$ EDTA. Isopropanol. 70\% ethanol.

\section{DNA isolation}

The leaves from the plants growing under natural conditions of Dichanthium annulatum, Heteropogon concortus, Sehima nervosum, Chrysopogon fulvus and Cenchrus glaucus were used in several treatment combinations to isolate genomic DNA. Leaves were homogenized in liquid nitrogen and fine powders were processed using extraction buffer. Extraction buffer ' $\mathrm{S}$ ' was exclusively used with Cenchrus glaucus to isolate the DNA. The fixing solutions ( $5 \mathrm{ml} / \mathrm{g}$ tissue) namely (A) absolute alcohol, (B) alcohol-chloroform (70:30), and (C) alcohol-0.5 M EDTA, [pH 8] (70:30) (Sharma et al. 2003) were also used to isolate the DNA without grinding the leaf samples in liquid nitrogen. Treated tissue was removed from solution and homogenized with a mortar and pestle.

Using a pre-chilled mortar and pestle $250 \mathrm{mg}$ of the sample was ground in the presence of liquid nitrogen. The frozen powder was transferred to extraction buffer (CTAB and buffer ' $\mathrm{S}$ ') containing 2-mercaptoethanol (3 to 6\%) and 1\% PVP and then mixed well and incubated at $65^{\circ} \mathrm{C}$ for $1 \mathrm{~h}$ in a water bath with occasional mixing by gentle swirling. After removing from water bath was cooled the mixture to room temperature. Then equal volume of chloroform-isoamylalcohol $(24: 1)$ was added. The mixture was mixes by inversion for $10 \mathrm{~min}$. After centrifugation at $10,000 \mathrm{rpm}$ $(8000 \mathrm{~g}$ ) for $10 \mathrm{~min}$, the resulting aqueous phase was transferred to another tube. The extraction with chloroform-isoamylalcohol $(24: 1)$ was repeated. Then 0.6 volume of isopropanol was added to aqueous phase to precipitate the DNA. DNA was recovered by centrifugation $10,000 \mathrm{rpm}$ for $10 \mathrm{~min}$ at $4{ }^{\circ} \mathrm{C}$. After decanting the supernatant, the sample was washed with $70 \%$ ethanol. The dried DNA was dissolved in $500 \mu \mathrm{l}$ of $1 \times \mathrm{TE}(\mathrm{pH} 8)$ and then treated with RNase $(10 \mu \mathrm{g} / \mathrm{ml}$ stock) for $1 \mathrm{~h}$ at $37^{\circ} \mathrm{C}$. To this was added $250 \mu \mathrm{l}$ of phenol and $250 \mu \mathrm{l}$ of chloroform-isoamylalchohol (24:1) and mixed thoroughly for $10 \mathrm{~min}$. Centrifugation was carried out for $15 \mathrm{~min}$ at $8000 \mathrm{~g}$. This procedure was repeated. After removing the organic phase, the DNA was precipitated by adding double the quantity of absolute alcohol. The DNA was washed with $70 \%$ ethanol and the DNA was resolved in $500 \mu \mathrm{l}$ of $1 \times \mathrm{TE}$ ( $\mathrm{pH} 8$ ). The DNA was diluted 1000 times in TE buffer and quantified by taking the optical density (OD) at $\lambda_{260}$ with a spectrophotometer. Readings at $\lambda_{280}$ was taken to obtain the $\lambda_{260} / \lambda_{280}$ ratio as an indicator of DNA purity (Sambrook et al. 1989). Purity of DNA was observed on $0.8 \%$ agarose gel after staining with ethidium bromide to ascertain its integrity.

\section{RAPD analysis}

Random amplification of polymorphic DNA (RAPD) analysis was performed with 5 primers using 25, 40, and $50 \mathrm{ng}$ of genomic DNA. After standardization (without smear and stutter bands), RAPD analysis was performed using DNA isolated from different methods of each grass species (Williams et al. 1990). Each PCR amplification was performed in a final volume of $20 \mu \mathrm{l}$ of reaction mixture containing $67 \mathrm{mM}$ Tris- $\mathrm{HCl}(\mathrm{pH} 8), 16.6 \mathrm{mM}\left(\mathrm{NH}_{4}\right)_{2} \mathrm{SO}_{4}, 0.45 \%(\mathrm{v} / \mathrm{v})$ Triton X-100, $4 \mu \mathrm{g}$ BSA, $3.5 \mathrm{mM} \mathrm{MgCl}_{2}, 150 \mu \mathrm{M}$ of each of dATP, dCTP, dGTP and dTTP, $7.5 \mathrm{pmol}$ (15 ng) primer, 25, 40 and $50 \mathrm{ng}$ genomic DNA templates and 0.5 unit Taq polymerase (Bangalore Genei, 
India), and finally it was overlaid by 5-10 $\mu$ l light mineral oil. Amplifications were performed on a DNA thermal cycler PTC-200 (MJ Research, USA) with the cycling program consisting of $94^{\circ} \mathrm{C}$ for $1 \mathrm{~min}, 37^{\circ} \mathrm{C}$ for $1 \mathrm{~min}$ and $72^{\circ} \mathrm{C}$ for $2 \mathrm{~min}$ for 40 cycles followed by $41 \mathrm{st}$ cycle at $37^{\circ} \mathrm{C}$ for $1 \mathrm{~min}$ and finally at $72^{\circ} \mathrm{C}$ for 10 min extension. The amplified products were kept at $4{ }^{\circ} \mathrm{C}$ until loaded on to the gel. Amplification products were separated by electrophoresis on $1.6 \%$ agarose gel in $0.5 \times \mathrm{TBE}$ buffer ( $\mathrm{pH} 8)$ to which ethidium bromide $(0.5 \mu \mathrm{g} / \mathrm{ml})$ was added for visualization with UV light, and photographed using AlphaImager (Alpha Innotech Corporation, USA). Along with the unknown samples 100 base pair DNA ladder was also loaded to know the size of the amplified products.

\section{ISSR analysis}

Inter-simple sequence repeat-PCR (ISSR-PCR) is a simple, cost efficient, robust, multilocus marker method, which is extensively useful in determining genetic variability. Therefore, isolated DNA was subjected to ISSR analysis. Single primer was used in each PCR reaction/experiment, which had a final volume of $25 \mu$. The reaction mixtures contained $2.5 \mu \mathrm{l}$ of $10 \times$ buffer $(67 \mathrm{mM}$ Tris- $\mathrm{HCl}(\mathrm{pH} 8), 16.6 \mathrm{mM}\left(\mathrm{NH}_{4}\right)_{2} \mathrm{SO}_{4}, 0.45 \%$ (v/v) Triton X-100, $\left.4 \mu \mathrm{g} \mathrm{BSA}\right), 2.0 \mu \mathrm{l}$ of $25 \mathrm{mM}$ $\mathrm{MgCl}_{2}, 1.5 \mu \mathrm{l}$ of $2.5 \mathrm{mM}$ dNTP, $2.0 \mu \mathrm{l}$ primer $(0.5 \mu \mathrm{M}), 0.1 \%$ gelatin, 1 unit Taq polymerase (Bangalore Genei, India) and 25, 40 and $50 \mathrm{ng}$ genomic DNA. The PCR reactions were performed on thermal cycler PTC-200 (MJ Research, USA) with cycling program consisting $94^{\circ} \mathrm{C}$ for $4 \mathrm{~min}$, followed by 35 cycles of denaturing at $94^{\circ} \mathrm{C}$ for $30 \mathrm{~s}$, annealing for $1 \mathrm{~min}$ at $50^{\circ} \mathrm{C}$, extension at $72^{\circ} \mathrm{C}$ for $90 \mathrm{~s}$, and final extension at $72^{\circ} \mathrm{C}$ for $7 \mathrm{~min}$. The amplification products were first mixed with loading buffer ( $40 \%$ sucrose and $0.25 \%$ bromophenol blue) and size separated by a standard horizontal electrophoresis on $1.6 \%$ agarose gel in $0.5 \times \mathrm{TBE}$ buffer under room temperature at a constant voltage of $70 \mathrm{~V}$ and detected by ethidium bromide staining, and photographed using AlphaImager (Alpha Innotech Corporation, USA).

\section{STS analysis}

Sequence-tagged-sites (STS) primers are specifically used in studying the species relationships developed on the basis of gene sequences or single copy genes. The isolated DNA was also subjected to visualize the STS patterns, as it would generate DNA profile useful to explore the progenitors or genome analysis. The polymerase chain reaction (PCR) amplification for STS loci followed the procedure described by Liu et al. (1996) with modification in genomic DNA concentration and inclusion of primer extension step for $5 \mathrm{~min}$ as a last step of amplification. The total reaction volume was $25 \mu$ l, which contained 78.2 mM Tris-HCL (pH 8.8), $19.4 \mathrm{mM}\left(\mathrm{NH}_{4}\right)_{2} \mathrm{SO}_{4}, 0.53 \%$ (v/v) Triton $\mathrm{X}-100,233 \mu \mathrm{g} / \mathrm{ml}$ BSA, $5.8 \mathrm{mM} \mathrm{MgCl}{ }_{2}, 130 \mathrm{mM}$ dNTPs, $0.3 \mu \mathrm{M}$ of primers, 1.2 unit of Taq DNA polymerase (Bangalore Genei, India) and 25, 40 and $50 \mathrm{ng}$ of genomic DNA templates. The reactions were overlaid with mineral oil. The PCR protocol was as follows: 32 cycles of $94^{\circ} \mathrm{C} / 60 \mathrm{~s}$, $55^{\circ} \mathrm{C} / 60 \mathrm{~s}, 72^{\circ} \mathrm{C} / 90 \mathrm{~s}$; one cycle at $72^{\circ} \mathrm{C} / 5 \mathrm{~min}$; and $4^{\circ} \mathrm{C}$ soak in an MJ Research PTC-200. Amplification products were separated on $1.8 \%$ agarose gels in $0.5 \times \mathrm{TBE}$ buffer and visualized by staining with ethidium bromide.

\section{Restriction analysis of DNA}

DNA was restricted by Hind III (Bangalore Genei, India) using $5 \mathrm{U} / \mu \mathrm{g}$ of DNA. The reaction mixture was incubated at $37^{\circ} \mathrm{C}$ overnight. Digested DNA was separated on $0.8 \%$ agarose gel, stained with ethidium bromide and observed under UV light.

\section{Results and discussion}

The major problem associated with tropical grasses are the presence of high level of polysac- 


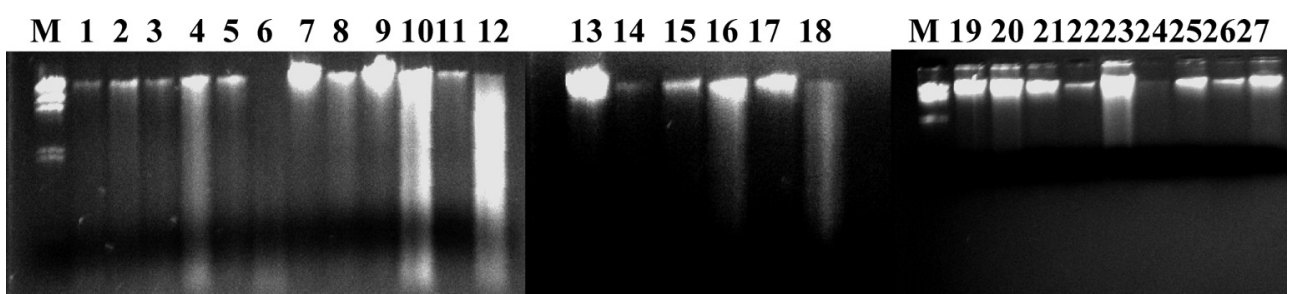

Fig. 1. Genomic DNA isolated from 5 species of tropical grasses applying the protocols mentioned in Table 1. Lanes 1-6: Dichanthium annulatum; lanes 7-12: Heteropogon concortus; lanes 13-18: Chrysopogon fulvus; lanes 19-24: Sehima nervosum and lanes 25-27: Cenchrus glaucus. DNA in lane numbers $6,12,18,24$ were isolated after fixing the tissues in alcohol.

charides including lignin which have been observed to interfere with DNA isolation procedure and inhibit the activity of a wide range of DNA-modifying enzymes, such as restriction enzymes, polymerase, and ligases. This has also hinders in grinding the sample when fixing solution was used to isolate the genomic DNA. This makes inevitable to use liquid nitrogen. The grinding of sample in absence of liquid nitrogen was very difficult and also leads to complete degradation of DNA.

The procedure reported yielded high molecular weight DNA ( $>40 \mathrm{~Kb}$, Fig. 1) after grinding the leaves in liquid nitrogen and using $2 \times \mathrm{CTAB}$ buffer with 3 to $6 \% 2$-mercaptoethanol along with $1 \%$ PVP (Table 1). The $\lambda_{260} / \lambda_{280}$ ratio was greater than 1.7 (ranging from 1.68 to 2.4 ) indicating DNA purity (Sambrook et al. 1989, Henry 1997) (Table 2). DNA yield ranged from 110-345 $\mu \mathrm{g} / \mathrm{g}$ among 5 species of tropical grasses when $2 \times$ CTAB with $3 \% 2$-mercaptoethanol and, $1 \times$ CTAB with 6\% 2-mercaptoethanol was used (Table 1).

Tissues fixed in 3 fixing solutions $\mathrm{A}, \mathrm{B}$ and $\mathrm{C}$ for a period of 30 to $60 \mathrm{~min}$ and ground in absence of liquid nitrogen surprisingly either did not yield or very insignificant amount of intact DNA. All DNA got degraded and thus not useful for any molecular biology work. However, exception was observed with $S$. nervosum which produced $115 \mu \mathrm{g} / \mathrm{g}$ DNA with $\lambda_{260} / \lambda_{280}$ ratio of 1.76 (Table 1). Sharma et al. (2003) have reported the isolation of intact DNA after fixing the tissue is above fixing solution and argued that treatment was sufficient to denature enzyme and desiccate the leaves. However, in case of tropical grasses the protocol has not worked may be due to presence of high amount of polysaccharides including lignin hindering the complete desiccation of leaf samples. There is also likelihood that the presence of high polysaccharides slows down the penetration of fixing solution and thus slows tissue death. DNA from C. glaucus, specifically, was obtained only when buffer ' $\mathrm{S}$ ' was applied. The yield of the DNA was $265 \mu \mathrm{g} / \mathrm{g}$ and $\lambda_{260} / \lambda_{280}$ ratio was 2.03 . As buffer ' $S$ ' has SDS instead of CTAB and therefore, possibly did not generate any complex substances which was otherwise formed when CTAB was used and finally hinders the release of DNA. Less than $1.8 \lambda_{260} / \lambda_{280}$ ratio indicated impaired DNA quality and this may be due to difference in levels of polysaccharides, fibers and associated anti-quality factors in plant species.

Samples ground in liquid nitrogen produced good quality DNA. The concentration of 2-mercaptoethanol (3 to 6\%) along with 1\% PVP yielded good quality genomic DNA. The yield of the DNA was better when 3\% 2-mercaptoethanol was used with $2 \times$ CTAB buffer (145 to $345 \mu \mathrm{g} / \mathrm{g}$ ) over $1 \times \mathrm{CTAB}$ with $3 \%$ 2-mercaptoethanol (120 to $315 \mu \mathrm{g} / \mathrm{g}$ ). In case of Dichanthium and Sehima yield was even more when concentration of 2-mercaptoethanol was increased from 3 to $6 \%$, however, the yield of DNA decreased in case of Chrysopogon and Heteropogon (Table 1). Overall less yield obtained with Dichanthium (120 to $180 \mu \mathrm{g} / \mathrm{g}$ ) was because of higher level of polysaccharides present in the plant. We obtained DNA yield and quality similar to results reported with other protocols (Murray and Thompson 1980, Callahan and Mehta 1991, Henry 1997, Khan et al. 2004, Kumar et al. 2003, Sharma et al. 2003). 
Table 1. Comparison among 3 protocols and over the standard

\begin{tabular}{|c|c|c|c|c|c|c|}
\hline \multirow{2}{*}{ Item } & \multicolumn{6}{|c|}{ Protocols } \\
\hline & 1 & 2 & 3 & 4 & 5 & 6 \\
\hline $\begin{array}{l}\text { Amount of liquid nitrogen } \\
\text { ground powder }\end{array}$ & $200 \mathrm{mg}$ & $200 \mathrm{mg}$ & $200 \mathrm{mg}$ & $200 \mathrm{mg}$ & $200 \mathrm{mg}$ & $\begin{array}{l}200 \mathrm{mg} \\
\text { leaves fixed } \\
\text { in alcohol }\end{array}$ \\
\hline $\begin{array}{l}\text { CTAB buffer conc., }+1 \% \text { PVP, } \\
\text { condition and volume (in case } \\
\text { of } C \text {. glaucus buffer ' } \mathrm{S} \text { ') }\end{array}$ & $\begin{array}{l}2 \times, \text { cold } \\
400 \mu 1\end{array}$ & $\begin{array}{l}1 \times, \text { pre-warm, } \\
\quad 400 \mu 1\end{array}$ & $\begin{array}{l}1 \times, \text { cold } \\
400 \mu 1\end{array}$ & $\begin{array}{l}1 \times, \text { cold } \\
400 \mu 1\end{array}$ & $\begin{array}{l}2 \times, \text { cold } \\
400 \mu \mathrm{l}\end{array}$ & $\begin{array}{l}1 \times, \text { cold } \\
400 \mu 1\end{array}$ \\
\hline 2-mercaptoethanol & $3 \%$ & $3 \%$ & $3 \%$ & $4.5 \%$ & $6 \%$ & $3 \%$ \\
\hline $\begin{array}{l}\text { Incubation temperature and } \\
\text { period }\end{array}$ & $\begin{array}{l}65^{\circ} \mathrm{C} \\
45 \mathrm{~min}\end{array}$ & $\begin{array}{l}65^{\circ} \mathrm{C} \\
45 \mathrm{~min}\end{array}$ & $\begin{array}{l}65^{\circ} \mathrm{C} \\
45 \mathrm{~min}\end{array}$ & $\begin{array}{l}65^{\circ} \mathrm{C} \\
45 \mathrm{~min}\end{array}$ & $\begin{array}{l}65^{\circ} \mathrm{C} \\
45 \mathrm{~min}\end{array}$ & $\begin{array}{l}65^{\circ} \mathrm{C} \\
45 \mathrm{~min}\end{array}$ \\
\hline $\begin{array}{l}\text { Chloroform-isoamylalcohol } \\
\qquad(24: 1)\end{array}$ & $400 \mu 1$ & $400 \mu 1$ & $400 \mu 1$ & $400 \mu \mathrm{l}$ & $400 \mu \mathrm{l}$ & $400 \mu 1$ \\
\hline $\begin{array}{l}\text { Precipitating solvent and } \\
\quad \text { volume }\end{array}$ & $\begin{array}{l}\text { Isopropanol } \\
\text { ( } 0.6 \text { volume })\end{array}$ & $\begin{array}{l}\text { Isopropanol } \\
\text { ( } 0.6 \text { volume })\end{array}$ & $\begin{array}{l}\text { Ethanol } \\
(0.6 \text { volume })\end{array}$ & $\begin{array}{l}\text { Isopropanol } \\
(1: 1 \text { volume })\end{array}$ & $\begin{array}{l}\text { Isopropanol } \\
\text { (0.6 volume) }\end{array}$ & $\begin{array}{l}\text { Isopropanol } \\
\text { ( } 0.6 \text { volume })\end{array}$ \\
\hline DNA yield and quality & \multicolumn{5}{|c|}{$\begin{array}{l}\text { DNA yield is better than the standard procedure, } \\
\text { quality is comparable }\end{array}$} & $\begin{array}{l}\text { Low and } \\
\text { degraded }\end{array}$ \\
\hline Dichanthium annulatum & $140 \mu \mathrm{g} / \mathrm{g}$ & $140 \mu \mathrm{g} / \mathrm{g}$ & $120 \mu \mathrm{g} / \mathrm{g}$ & $210 \mu \mathrm{g} / \mathrm{g}$ & $180 \mu \mathrm{g} / \mathrm{g}$ & Nil \\
\hline Chrysopogon fulvus & $190 \mu \mathrm{g} / \mathrm{g}$ & $135 \mu \mathrm{g} / \mathrm{g}$ & $160 \mu \mathrm{g} / \mathrm{g}$ & $135 \mu \mathrm{g} / \mathrm{g}$ & $160 \mu \mathrm{g} / \mathrm{g}$ & $45 \mu \mathrm{g} / \mathrm{g}$ \\
\hline Heteropogon concortus & $345 \mu \mathrm{g} / \mathrm{g}$ & $175 \mu \mathrm{g} / \mathrm{g}$ & $315 \mu \mathrm{g} / \mathrm{g}$ & $180 \mu \mathrm{g} / \mathrm{g}$ & $110 \mu \mathrm{g} / \mathrm{g}$ & $40 \mu \mathrm{g} / \mathrm{g}$ \\
\hline Sehima nervosum & $155 \mu \mathrm{g} / \mathrm{g}$ & $240 \mu \mathrm{g} / \mathrm{g}$ & $230 \mu \mathrm{g} / \mathrm{g}$ & $175 \mu \mathrm{g} / \mathrm{g}$ & $245 \mu \mathrm{g} / \mathrm{g}$ & $115 \mu \mathrm{g} / \mathrm{g}$ \\
\hline Cenchrus glaucus & $265 \mu \mathrm{g} / \mathrm{g}$ & - & - & - & - & - \\
\hline
\end{tabular}

Table 2. DNA yield and purity obtained with the present protocol from different species of tropical grasses

\begin{tabular}{|c|c|c|c|c|c|}
\hline Species/protocol no. & $\mathrm{OD}, \lambda_{260}$ & $\mathrm{OD}, \lambda_{280}$ & $\mathrm{OD}, \lambda_{260} / \lambda_{280}$ & Concentration, $\mu \mathrm{g} / 1$ & DNA yield, $\mu \mathrm{g} / \mathrm{g}$ \\
\hline D. annulatum (1) & 0.028 & 0.012 & 2.33 & 0.140 & 140 \\
\hline D. annulatum (2) & 0.028 & 0.015 & 1.86 & 0.140 & 140 \\
\hline D. annulatum (3) & 0.024 & 0.012 & 2.00 & 0.120 & 120 \\
\hline D. annulatum (4) & 0.042 & 0.020 & 2.10 & 0.210 & 210 \\
\hline D. annulatum (5) & 0.036 & 0.019 & 1.89 & 0.180 & 180 \\
\hline D. annulatum (6) & -0.020 & -0.001 & - & - & - \\
\hline C. fulvus (1) & 0.038 & 0.019 & 2.0 & 0.190 & 190 \\
\hline C. fulvus (2) & 0.027 & 0.016 & 1.68 & 0.135 & 135 \\
\hline C. fulvus (3) & 0.032 & 0.018 & 1.77 & 0.160 & 160 \\
\hline C. fulvus (4) & 0.027 & 0.015 & 1.86 & 0.135 & 135 \\
\hline C. fulvus (5) & 0.032 & 0.019 & 1.68 & 0.160 & 160 \\
\hline C. fulvus (6) & 0.009 & 0.010 & - & 0.045 & 45 \\
\hline H. concortus (1) & 0.069 & 0.037 & 1.86 & 0.345 & 345 \\
\hline H. concortus (2) & 0.035 & 0.018 & 1.94 & 0.175 & 175 \\
\hline H. concortus (3) & 0.063 & 0.035 & 1.86 & 0.315 & 315 \\
\hline H. concortus (4) & 0.036 & 0.020 & 1.80 & 0.180 & 180 \\
\hline H. concortus (5) & 0.022 & 0.012 & 1.80 & 0.110 & 110 \\
\hline H. concortus (6) & 0.008 & 0.007 & - & 0.040 & 40 \\
\hline S. nervosum (1) & 0.031 & 0.018 & 1.72 & 0.155 & 155 \\
\hline S. nervosum (2) & 0.048 & 0.020 & 2.40 & 0.240 & 240 \\
\hline S. nervosum (3) & 0.046 & 0.025 & 1.84 & 0.230 & 230 \\
\hline S. nervosum (4) & 0.035 & 0.020 & 1.75 & 0.175 & 175 \\
\hline S. nervosum (5) & 0.049 & 0.027 & 1.84 & 0.245 & 245 \\
\hline S. nervosum (6) & 0.023 & 0.013 & 1.76 & 0.115 & 115 \\
\hline C. glaucus & 0.053 & 0.026 & 2.03 & 0.265 & 265 \\
\hline
\end{tabular}




\section{M1 234556789101112131415161718192021222324}

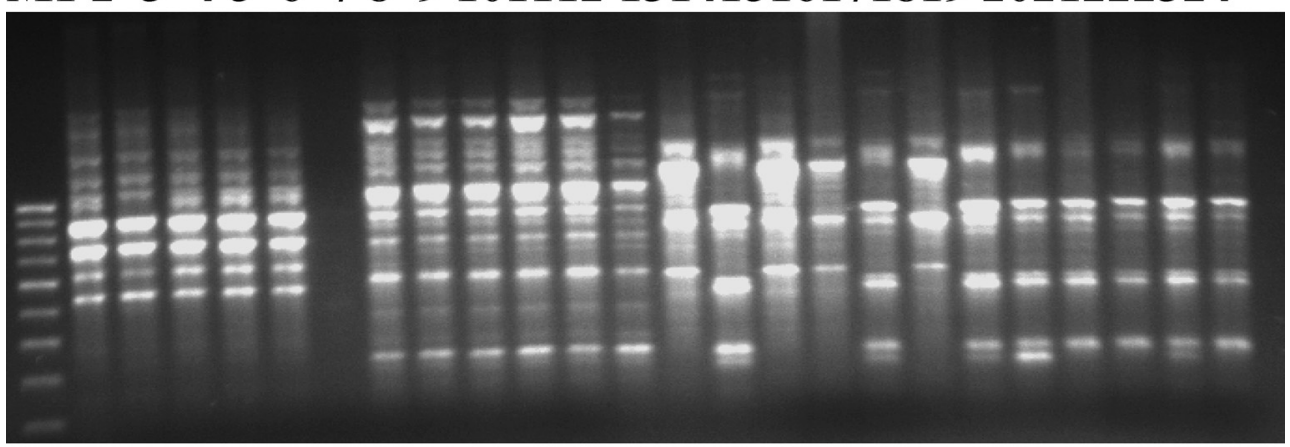

(A)

\section{123456789101112131415161718192021222324}

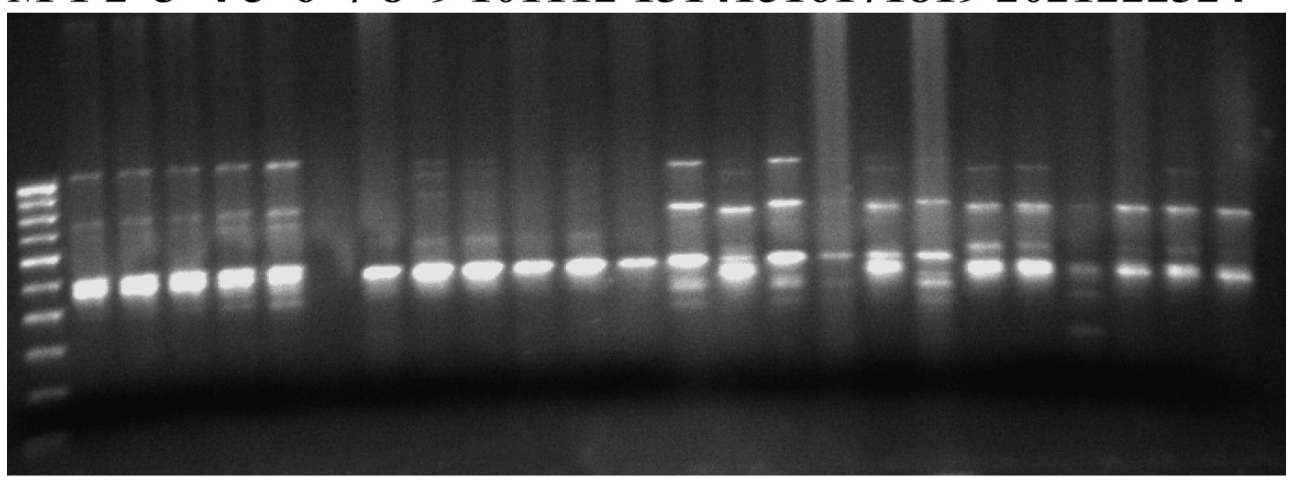

(B)

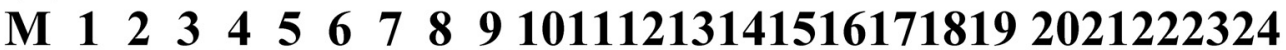

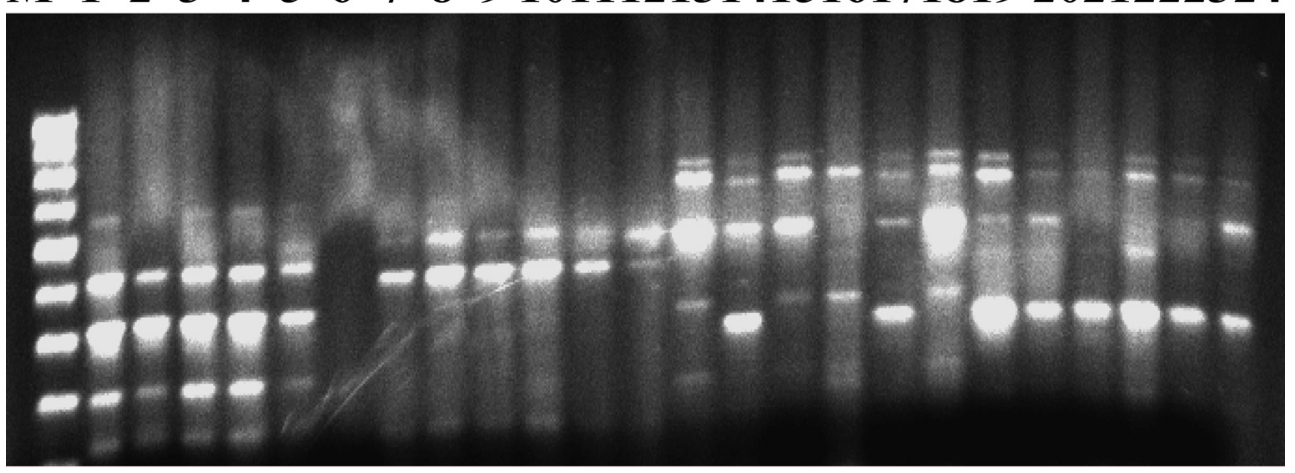

(C)

Fig. 2. ISSR (A), RAPD (B) and STS (C) profiles generated for Dichanthium annulatum (lanes 1-6); Heteropogon concortus (lanes 7-12); Chrysopogon fulvus (lanes 13-18); Sehima nervosum (lanes 19-24). M. 100 bp DNA ladder as a molecular weight marker.

PCR analysis

DNA isolated from 5 tropical grass species was amplified using 10-mer random primers from Operon Biotechnologies, Inc. (USA), ISSR primer ([GACA $]_{4}$ GT) and 2 pairs of STS primers (Liu et al. 1996). DNA isolated through 6 treatments combination (Table 1) was used for PCR amplifica- 


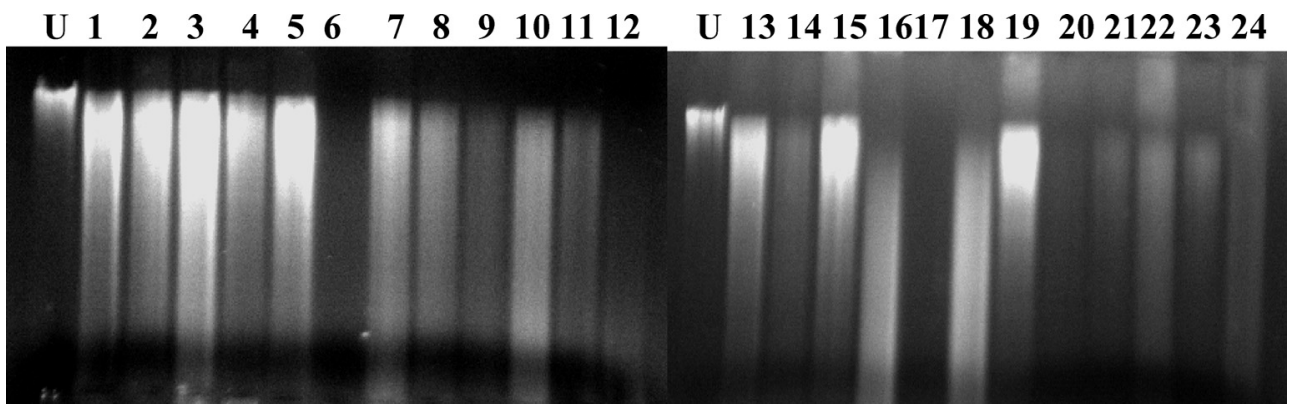

Fig. 3. HindIII cut genomic DNA isolated as per protocol mentioned in Table 1 from Dichanthium annulatum (lanes 1-6); Heteropogon concortus (lanes 7-12); Chrysopogon fulvus (lanes 13-18); Sehima nervosum (lanes 19-24). U=uncut DNA.

tions. DNA was diluted to $5 \mathrm{ng} / \mu \mathrm{l}$ in TE buffer, and $5 \mu \mathrm{l}, 8 \mu \mathrm{l}$, and $10 \mu \mathrm{l}$ of diluted DNA was used for amplification with 4 primers in total. When $25 \mathrm{ng}$ of DNA was used, bands without background smearing and upper DNA streaks were produced which were easily scorable (Fig. 2). A uniform DNA patterns was expected because DNA was from the same plants. Bands were uniform with all reactions, indicating good quality DNA. Genomic DNA isolated from C. glaucus also produced uniform patterns, regardless of different buffer used (buffer 'S').

\section{Restriction analysis of genomic DNA}

Genomic DNA from all 5 grass species was restricted by HindIII ( 5 unit of enzyme $/ \mu \mathrm{g}$ of DNA, kept overnight at $37^{\circ} \mathrm{C}$ ). The restricted DNA produced a good patterns on $0.8 \%$ agarose gel, indicating complete digestion of DNA samples from 2 buffers (Fig. 3).

In conclusion, genomic DNA isolated from 4 tropical grass species using $2 \times \mathrm{CTAB}$ buffer along with 3 to $6 \%$ 2-mercaptoethanol and 1\% PVP, and buffer ' $\mathrm{S}$ ' for C. glaucus DNA observed useful for routine molecular biological work. Grinding of leave tissues in liquid nitrogen found inevitable as alcohol fixed plant samples only yielded degraded and non-usable DNA for molecular biology work.

\section{Acknowledgements}

Authors are thankful to the Head of the Division and Director of the institute for providing the necessary faculties to carry out the present work. RS is also thankful to CSIR, New Delhi for providing the SRF.

\section{References}

Callahan, F. E. and Mehta, A. M. 1991. A rapid alkaline extraction procedure for screening recombinant plasmid DNA: a method for preparing plasmid DNA. Nucleic Acids Res. 7: 1513-1523.

Henry, R. J. 1997. Practical Applications of Plant Molecular Biology. 1st ed. Champman and Hall, London.

Khan, L. A., Ahmad, A. A. and Khan, A. A. 2004. A modified mini-prep method for economical and rapid extraction of genomic DNA in plants. Plant. Mol. Biol. Reptr. 22: 89.

Kumar, A., Pushpangadan, P. and Mehrotra, S. 2003. Extraction of high molecular weight DNA from dry root tissue of Berberis lycium suitable for RAPD. Plant. Mol. Biol. Reptr. 21: 309.

Liu, C. J., Musial, J. M. and Smith, F. W. 1996. Evidence for a low level of genomic specificity of sequence tagged sites in Stylosanthes. Theor. Appl. Genet. 93: 864-868.

Murray, M. G. and Thompson, W. F. 1980. Rapid isolation of high molecular weight DNA. Nucleic Acids Res. 8: 4321-4325.

Pandey, R. N., Adams, R. P. and Flournoy, L. E. 1996. Inhibition of random amplified polymorphic DNAs (RAPDs) by plant 
polysaccharides. Plant. Mol. Biol. Reptr. 14: 17-22.

Sambrook, J., Fritsch, E. F. and Maniatis, T. 1989. Molecular cloning: A Laboratory Manual, 2nd ed. Nolan, C. (ed.). Cold Spring Harbor Laboratory Press Cold Spring Harbor, New York.

Sharma, R., Mahla, H. R., Mohpatra, T., Bhargva and Sharma, M. M. 2003. Isolating plant genomic DNA without liquid nitrogen. Plant. Mol. Biol. Reptr. 21: 43-50.

Williams, J. G. K., Kubelik, A. R., Livak, K. T., Rafalski, J. A. and Tingey, S. V. 1990. DNA polymorphism amplified by arbitrary primers are useful as genetic markers. Nucleic Acids Res. 18: 6531. 